\title{
PM ALLOY 625M FOR HIGH STRENGTH CORROSION RESISTANT APPLICATIONS
}

\author{
by \\ Frank J. Rizzo \\ Crucible Compaction Metals \\ and \\ Steven Floreen \\ Knolls Atomic Power Laboratory
}

\begin{abstract}
In applications where the combination of high strength and good corrosion resistance are required, there have been only a few alloys of choice. Crucible Materials Corporation developed PM 625M, a niobium modification of Alloy 625, as a material to fill this need. One area of particular interest is the nuclear power industry, where many problems have been encountered with bolts, springs, and guidepins. Mechanical properties and stress corrosion cracking data of PM 625M are presented in this paper.
\end{abstract}




\section{INTRODUCTION}

For years the Nuclear Power industry has had a need for a high strength corrosion resistant material for applications such as bolting, support pins, etc. The alloys most often used in this service have been $\mathrm{X}$ 750,718 , and A-286 $6^{(1-3)}$. However, these alloys have shown a tendency to fail by stress corrosion cracking. In recent years, Crucible has developed a powder metal alloy PM 625M (UNS N06626) which is a high strength age-hardenable version of Alloy 625 . The PM alloy was designed to have the strength of conventional cast and wrought Alloy 718 with the corrosion resistance of Alloy 625.

PM 625M relies on the precipitation of $\gamma^{\prime \prime}\left(\mathrm{Ni}_{3} \mathrm{Nb}\right)^{(4)}$ for strengthening. The modification from Alloy 625 is primarily niobium $(1.25 \%$ higher) and this helps to boost the strength by making more niobium available for precipitation. The property of interest is the yield strength which can be selected to be between $827 \mathrm{MPa}(120 \mathrm{ksi}$ ) and $965 \mathrm{MPa}$ (140 ksi) depending on the aging treatment used. Corrosion resistance in many of the standard tests (e.g., pitting, crevice, or intergranular corrosion) is better than that of Alloy 718 and approaching that of Alloy $625^{(5)}$. This paper deals with the stress corrosion cracking behavior of PM $625 \mathrm{M}$ and how it compares to some of the other conventional alloys used in these environments.

\section{PREP $\Lambda$ RATION OF MATERIALS}

Powder for this investigation was produced in the Crucible Pilot Gas Atomizer. Portions of several 800 pound heats were screened to $-250 \mu$ (i.e, $-60 \mathrm{mesh}$ ) particle size and blended together to make a single master powder blend, 88IM375, for the program. The particle size is plotted in Figure 1 and shows that the powder was relatively fine. The apparent density and the tap density per ASTM standards B-212 and B-527 respectively are given in Table I. The values are typical of powder of this type. The chemical analyses of blend 88IM375 is given in Table II. All of the values are within the specified ranges for this alloy. The niobium level is $5.01 \%$, which is the only element outside the range for conventional cast and wrought Alloy 625 (UNS N06625).

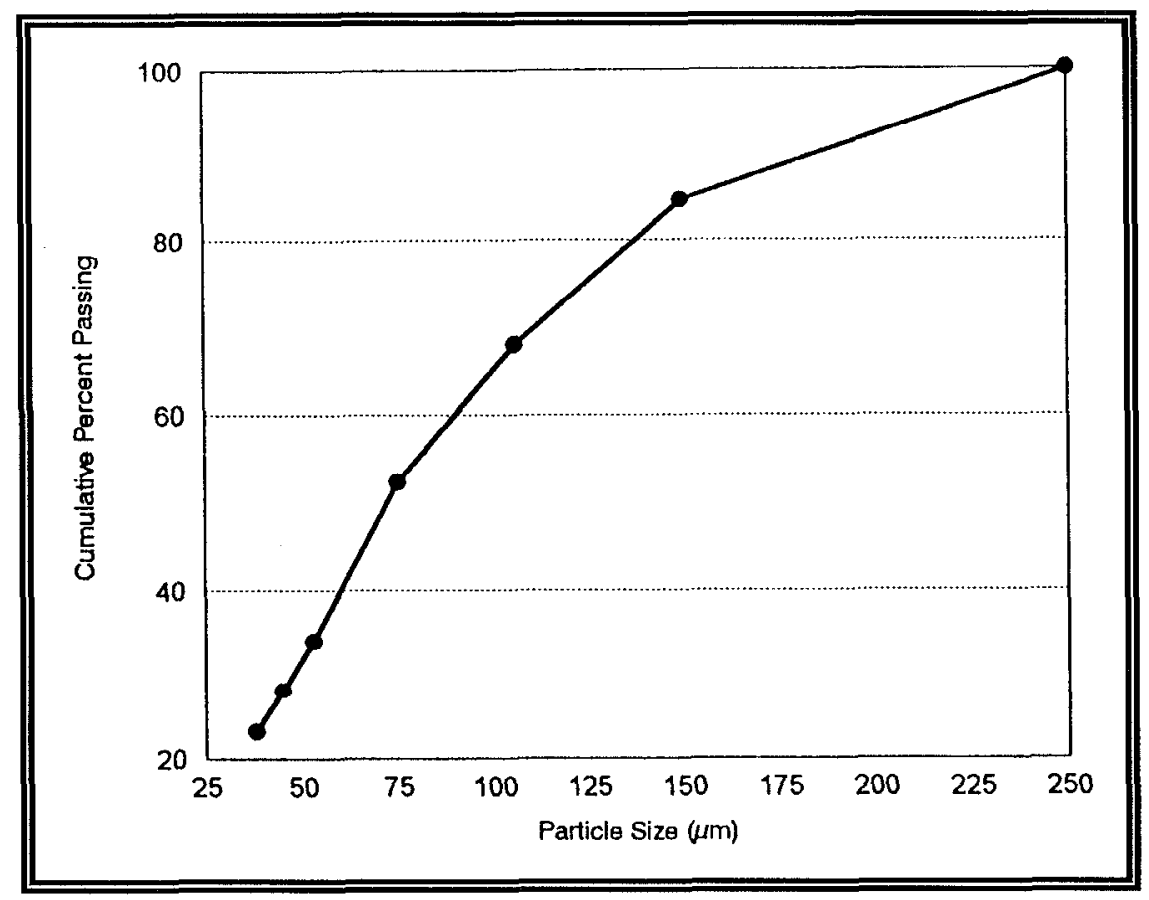

Figure 1. Powder Particle Size Distribution for PM 625M Blend 88IM375. 
TABLE I Apparent Density and Tap Density of PM 625M Blend 88IM375

\begin{tabular}{|c|c|}
\hline \hline Apparent Density & $5.14 \mathrm{~g} / \mathrm{cm}^{3}\left(0.185 \mathrm{lb} / \mathrm{in}^{3}\right)$ \\
\hline Tap Density & $5.68 \mathrm{~g} / \mathrm{cm}^{3}\left(0.205 \mathrm{lb} / \mathrm{in}^{3}\right)$ \\
\hline
\end{tabular}

TABLE II Chemical Analysis (wt\%) of PM 625M Blend 88IM375

\begin{tabular}{|c|c|c|c|}
\hline \hline $\mathrm{C}=0.028$ & $\mathrm{Cr}=20.67$ & $\mathrm{Co}=0.020$ & $\mathrm{O}=0.006$ \\
$\mathrm{Mn}=0.070$ & $\mathrm{Mo}=8.62$ & $\mathrm{Cu}=<0.01$ & $\mathrm{~N}=0.012$ \\
$\mathrm{Si}=0.140$ & $\mathrm{Nb}=5.01$ & $\mathrm{~W}=<0.02$ & \\
$\mathrm{~S}=0.005$ & $\mathrm{Ti}=0.07$ & $\mathrm{Fe}=4.93$ & \\
$\mathrm{P}=0.010$ & $\mathrm{Al}=0.40$ & $\mathrm{Ni}=$ Balance & \\
\hline
\end{tabular}

Three compacts were produced from this blend of powder; two were consolidated by HIP and one was consolidated by extrusion. The HIP bars (M1479 and M1480) were loaded, outgassed, sealed and HIP at $1130^{\circ} \mathrm{C}\left(2065^{\circ} \mathrm{F}\right)$ and $103 \mathrm{MPa}(15 \mathrm{ksi})$. The extrusion compact (M1481) was prepared in a similar manner to the HIP compacts and was extruded in a $23.5 \mathrm{~cm}(9.25 \mathrm{in})$ liner to approximately $4.8 \mathrm{~cm}(1.9$ in) in diameter. The temperature of extrusion was $1120^{\circ} \mathrm{C}\left(2050^{\circ} \mathrm{F}\right)$ and the compact was held for 8 hours at temperature prior to the push.

After consolidation, all of the bars were evaluated for density and microstructure. The density results are given in Table III and are considered typical for this alloy. A thermally induced porosity (TIP) test was also conducted on each compact to check for container leaks during consolidation and there were no adverse findings. The microstructure was fine grain equiaxed and the extruded bar exhibited some slight grain elongation in the longitudinal direction.

\begin{tabular}{|c|c|c|}
\hline \multicolumn{2}{|c|}{ TABLE III Density of Consolidated PM 625M Blend 88IM375 } \\
\hline Compact Code & Consolidation Process & $\begin{array}{c}\text { Density } \\
\mathrm{g} / \mathrm{cm}^{3}\left(\mathrm{lb} / \mathrm{in}^{3}\right)\end{array}$ \\
\hline \hline M1479 & Hot Isostatic Press & $8.42(0.304)$ \\
M1480 & Hot Isostatic Press & $8.42(0.304)$ \\
M1481 & Extrusion & $8.40(0.303)$ \\
\hline
\end{tabular}

\section{MECHANICAL PROPERTY EVALUATION}

Material from each densification condition was sectioned, prepared, and room temperature tensile tested in the as-consolidated state. These data appear in Table IV. The as-HIP material exhibited about a 103 $\mathrm{MPa}(15 \mathrm{ksi})$ higher ultimate tensile strength, a $138 \mathrm{MPa}(20 \mathrm{ksi})$ higher $0.2 \%$ yield strength, and about $10 \%$ lower ductilities than the extruded material. This was probably a result of the slow cooling rate in the HIP vessel when compared to the cool down of a small diameter bar just off the extrusion press. The bars were also room temperature tensile tested in the fully heat treated condition and after further thermal exposure at $427^{\circ} \mathrm{C}\left(800^{\circ} \mathrm{F}\right)$ for 500 hours. These data are presented in Table IV as well. The extruded material had slightly higher $0.2 \%$ yield strength and slightly higher ductility than the HIP material. However, these differences are not considered significant. The thermally exposed material had virtually the same tensile properties as the fully heat treated material. 


\begin{tabular}{|c|c|c|c|c|c|c|c|}
\hline $\begin{array}{l}\text { Compact } \\
\text { Code }\end{array}$ & $\begin{array}{l}\text { Consolidation } \\
\text { Process }\end{array}$ & $\begin{array}{c}\text { Thermal } \\
\text { Condition }{ }^{(1)}\end{array}$ & $\begin{array}{l}\text { UTS } \\
\text { MPa (ksi) }\end{array}$ & $\begin{array}{l}0.2 \% \text { YS } \\
\text { MPa (ksi) }\end{array}$ & $\begin{array}{c}\text { Elong } \\
(\%)\end{array}$ & $\begin{array}{l}\text { RA } \\
(\%)\end{array}$ & $\begin{array}{l}\text { Charpy } \\
\text { "V" Notch } \\
\text { Impact }\end{array}$ \\
\hline M1479 & HIP & As-HIP & $(137.0)$ & $536 \quad(77.8)$ & 50.0 & 47.3 & - \\
\hline M1479 & HIP & A & $1256 \quad(182.2)$ & $908 \quad(131.8)$ & 25.5 & 26.9 & - \\
\hline M1480 & HIP & A & $1248 \quad(181.0)$ & $910 \quad(137.0)$ & 28.0 & 30.0 & $32.5(24.0)$ \\
\hline M1480 & HIP & B & $1227(178.0)$ & $917(133.0)$ & 35.0 & 41.0 & $36.9(27.2)$ \\
\hline M1481 & Extrude & A & $(179.0)$ & $903 \quad(131.0)$ & 33.0 & 31.0 & $46.3(34.2)$ \\
\hline M1481 & Extrude & B & $(179.0)$ & $896(130.0)$ & 36.0 & 39.0 & $45.8(33.8)$ \\
\hline
\end{tabular}

Charpy "V"-notch impact tests were also conducted on material consolidated by both methods in the heat treated and heat treated plus thermally exposed conditions. Table IV contains these data also. Extruded material exhibited about an $11 \mathrm{~J}(8 \mathrm{ft}-\mathrm{lb})$ advantage over the HIP material. However, the thermal exposure appeared to have no significant effect on impact values.

\section{MICROSTRUCTURAL CHARACTERISTICS}

Examination of PM $625 \mathrm{M}$ on the SEM shows that in the fully heat treated condition, the matrix contains $\mathrm{Nb}$-rich $\mathrm{MC}$ and Mo-rich $\mathrm{M}_{6} \mathrm{C}$ carbides and considerable $\gamma^{\prime \prime}\left(\mathrm{Ni}_{3} \mathrm{Nb}\right)$. Figure 2 shows a photomicrograph of PM $625 \mathrm{M}$ in the fully heat treated condition. The carbides are present in the as-consolidated condition and the $\gamma^{\prime \prime}$ precipitates during the heat treatment cycle. This aging response of the PM 625 and $625 \mathrm{M}$ alloys was reported previously ${ }^{(6,7)}$.

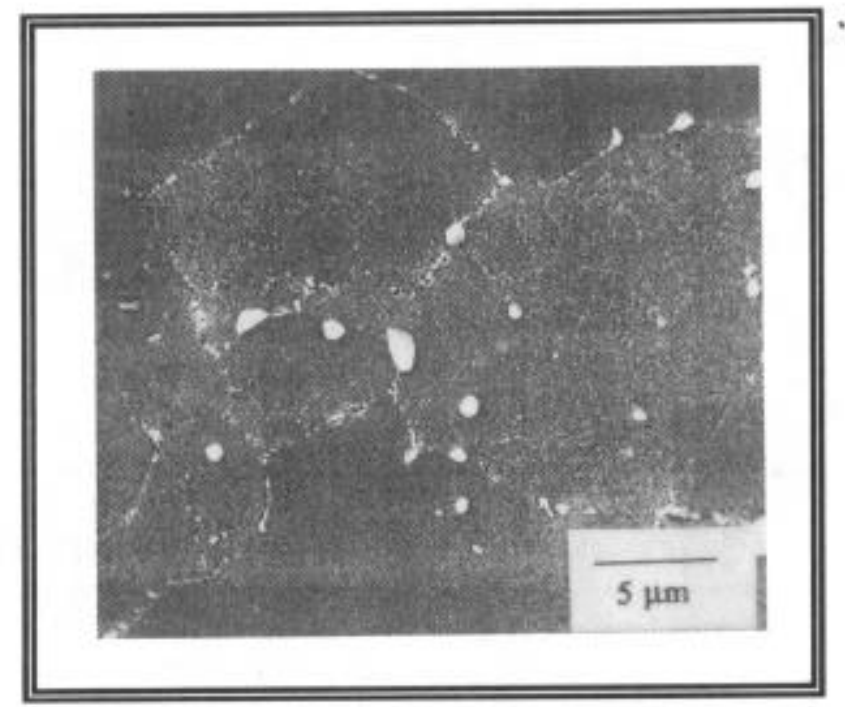

Figure 2. SEM Photograph of PM 625M in the Fully Heat Treated Condition.

Heat Treatment $=718^{\circ} \mathrm{C}\left(1325^{\circ} \mathrm{F}\right) / 8 \mathrm{hrs} / \mathrm{FC} 55^{\circ} \mathrm{C}\left(100^{\circ} \mathrm{F}\right) / \mathrm{hr}$ to $621^{\circ} \mathrm{C}\left(1150^{\circ} \mathrm{F}\right) / 8 \mathrm{hrs} / \mathrm{AC}$. 


\section{STRESS CORROSION TEST RESULTS}

Test samples were taken from $38 \mathrm{~mm}$ (1.5 in) diameter bar stock lengths that had been consolidated by extrusion and HIP respectively and subsequently double aged at $718^{\circ} \mathrm{C}\left(1325^{\circ} \mathrm{F}\right) / 8 \mathrm{hrs} /$ Furnace Cool $55^{\circ} \mathrm{C}$ $\left(100^{\circ} \mathrm{F}\right) / \mathrm{hr}$ to $621^{\circ} \mathrm{C}\left(1150^{\circ} \mathrm{F}\right) / 8 \mathrm{hrs} / \mathrm{Air}$ Cool. A number of $10 \mathrm{~mm}(0.4 \mathrm{in})$ compact tension fracture toughness specimens were machined from the bar stock with precracks oriented in the transverse direction (i.e., running across the bar). In addition, a set of fracture toughness specimens were machined from extruded material in the longitudinal direction with precracks running down the bar length to determine the effect of orientation on stress corrosion cracking behavior.

The majority of the specimens were tested in the fully heat treated condition. In addition, portions of both materials were given a thermal exposure at $427^{\circ} \mathrm{C}\left(800^{\circ} \mathrm{F}\right)$ for 500 hours before specimen machining. This thermal exposure was intended as a screening test to see if the alloy was susceptible to changes in corrosion properties during long-time service at lower temperatures.

The compact tension specimens were fatigue precracked and bolt loaded to nominal stress intensities of either 50 or $65 \mathrm{MPa} \sqrt{\mathrm{m}}(45.5$ or $59.1 \mathrm{ksi} \sqrt{\mathrm{in}})$. These samples were tested in deaerated (1 to $2 \mathrm{ppb}$ oxygen) $\mathrm{pH} 10$ water at either $288^{\circ} \mathrm{C}$ or $360^{\circ} \mathrm{C}\left(550^{\circ} \mathrm{F}\right.$ or $\left.680^{\circ} \mathrm{F}\right)$. The samples were periodically removed from test and inspected for signs of stress corrosion crack growth. No crack growth could be detected on the sides of the samples during exposures. After various exposure times, samples were removed from test and broken open at room temperature. The fracture surfaces were then examined by optical and scanning electron microscopy for signs of intergranular crack growth.

\begin{tabular}{|c|c|c|c|c|c|c|c|c|c|}
\hline \multirow{4}{*}{$\begin{array}{c}\text { Compact } \\
\text { Code }\end{array}$} & \multirow{4}{*}{$\begin{array}{c}\begin{array}{c}\text { Consolidation } \\
\text { Process }\end{array} \\
\begin{array}{c}\text { HIP } \\
\text { " }\end{array}\end{array}$} & \multirow{4}{*}{$\begin{array}{c}\begin{array}{c}\text { Thermal } \\
\text { Condition }\end{array} \\
\mathrm{A}\end{array}$} & \multirow{2}{*}{\multicolumn{2}{|c|}{$\begin{array}{c}\text { Test } \\
\text { Temperature } \\
{ }^{\circ} \mathrm{C} \quad\left({ }^{\circ} \mathrm{F}\right)\end{array}$}} & \multirow{2}{*}{$\begin{array}{c}\text { Test } \\
\text { Duration } \\
\text { (Days) }\end{array}$} & \multirow{2}{*}{\multicolumn{2}{|c|}{$\begin{array}{c}\text { Initial Stress } \\
\text { Intensity } \\
\mathrm{MPa} / \mathrm{m}(\mathrm{ksi} / \mathrm{m})\end{array}$}} & \multicolumn{2}{|c|}{$\begin{array}{c}\text { Max } \\
\text { SCC Depth }\end{array}$} \\
\hline & & & & & & & & $\mathrm{mm}$ & (in) \\
\hline & & & 360 & $(680)$ & 448 & 49.5 & $(45.1)$ & 0.05 & $(0.002)$ \\
\hline & & & 360 & $(680)$ & 711 & 65.9 & $(60.0)$ & 0.14 & $(0.006)$ \\
\hline 1480 & $"$ & $\mathrm{~B}$ & 360 & $(680)$ & 448 & 49.5 & $(45.1)$ & & 0 \\
\hline 1480 & $"$ & B & 360 & (680) & 711 & 66.1 & $(60.2)$ & & 0 \\
\hline 1480 & HIP & A & 288 & $(550)$ & 841 & 65.9 & $(60.0)$ & 0.08 & $(0.003)$ \\
\hline 1480 & " & A & 288 & (550) & 841 & 64.7 & (58.9) & 0.13 & $(0.005)$ \\
\hline 1480 & $"$ & B & 288 & $(550)$ & 841 & 65.5 & $(59.6)$ & 0.10 & $(0.004)$ \\
\hline 1480 & $"$ & B & 288 & $(550)$ & 841 & 65.6 & $(59.7)$ & 0.13 & $(0.005)$ \\
\hline 1481 & Extrusion & A & 360 & (680) & 448 & 49.7 & $(45,2)$ & & 0 \\
\hline 1481 & " & A & 360 & (680) & 711 & 65.9 & $(60.0)$ & & 0 \\
\hline $1481^{(2)}$ & $"$ & A & 360 & (680) & 448 & 50.0 & (45.5) & 0.05 & $(0.002)$ \\
\hline $1481^{(2)}$ & " & A & 360 & (680) & 711 & 66.1 & $(60.2)$ & 0.14 & $(0.006)$ \\
\hline 1481 & $"$ & B & 360 & (680) & 448 & 49.3 & $(44.9)$ & & 0 \\
\hline 1481 & $"$ & B & 360 & (680) & 711 & 65.0 & $(44.9)$ & & 0 \\
\hline 1481 & Extrusion & A & 288 & $(550)$ & 841 & 66.4 & $(60.4)$ & & 0 \\
\hline 1481 & " & A & 288 & $(550)$ & 841 & 65.2 & (59.3) & & 0 \\
\hline $1481^{(2)}$ & $"$ & $A$ & 288 & (550) & 841 & 66.4 & $(60.4)$ & 0.14 & $(0.006)$ \\
\hline $1481^{(2)}$ & $"$ & $\mathrm{~A}$ & 288 & (550) & 841 & 65.6 & $(59.7)$ & & ) \\
\hline 1481 & $"$ & $\mathrm{~B}$ & 288 & (550) & 841 & 65.8 & $(59.9)$ & & 0 \\
\hline 1481 & " & $B$ & 288 & (550) & 841 & 65.5 & $(59.6)$ & & 0 \\
\hline & $\begin{aligned} \text { (1) } \mathrm{A}=718^{\circ} \mathrm{C} \\
\mathrm{B}=\mathrm{A} \text { plu } \\
\text { (2) Specimen }\end{aligned}$ & $\begin{array}{l}\left.25^{\circ} \mathrm{F}\right) 8 \mathrm{hrs} / \mathrm{Furm} \\
{ }^{\circ} \mathrm{C}\left(800^{\circ} \mathrm{F}\right) / 50 \\
\text { acked with a L }\end{array}$ & itudin & $\begin{array}{l}\left(100^{\circ} \mathrm{F}\right) \\
\text { ientatio }\end{array}$ & $\mathrm{r}$ to $621^{\circ} \mathrm{C}$ & $0^{\circ} \mathrm{F} / 8$ & $\mathrm{Cool}$ & & \\
\hline
\end{tabular}

These results are summarized in Table V. Many of the specimens showed no stress corrosion crack growth after exposure times up to 841 days. In some samples, localized small thumb nail shaped regions 
of stress corrosion crack growth were detected. These regions were typically about $0.5 \mathrm{~mm}(0.020 \mathrm{in})$ wide and about $0.1 \mathrm{~mm}(0.004 \mathrm{in})$ deep. This type of cracking was more noticeable in the HIP material than in the extruded stock. In the extruded materials crack growth was only detected in the longitudinal orientation. The $427^{\circ} \mathrm{C}\left(800^{\circ} \mathrm{F}\right)$ thermal exposure did not promote crack growth, indicating that long-time service exposures would not degrade the stress corrosion resistance of PM 625M.

\section{CONCLUSIONS}

The overall results indicate that Alloy PM 625M has excellent resistance to stress corrosion in a high purity water environment. In comparison, tests of other commonly used precipitation hardened nickel base alloys such as Alloy X-750 and Alloy 718 generally show about an order of magnitude greater crack growth after exposure times on the order of 100 days in tests of this kind. Thus Alloy PM 625M would appear to be worthy of consideration for light water reactor applications requiring high strength and good corrosion resistance.

\section{$\underline{\text { References }}$}

1) A. R. McIlree, "Degradation of High Strength Austenitic Alloys X-750, 718, and A-286 in Nuclear Power systems" NACE, Houston, Texas, 1984, pp 838-850.

2) M. T. Miglin, J. V. Monter, C. S. Wade and J. L. Nelson, "Effect of Heat Treatment on Stress Corrosion of Alloy 718 in Pressurized-Water-Reactor Primary Water" Proceedings from the Fifth International Symposium on Environmental Degradation of Materials in Nuclear Power Systems Water Reactors, Monterey, California, August 25-29, 1991, pp 279-286.

3) W. L. Kimmerle, M. T. Miglin and J. L. Nelson, "Stress Corrosion Cracking of Alloy 718 in Pressurized-Water-Reactor Primary Water" (Paper presented at Superalloy 718 - Metallurgy and Applications), Pittsburgh, Pennsylvania, June 12-14, 1989.

4) A. M. Dalley and C. C. Fisher, "TEM Investigation of PM Inconel 625 Alloys"(Report prepared by the RJ Lee Group, Inc. for Crucible Materials Corp., June 6, 1989).

5) F. J. Rizzo and S. B. Justus, "PM Alloy 625M - A High Strength Modification of Alloy 625"(Paper presented at Superalloys 718,625,706 and Various Derivatives, Pittsburgh, Pennsylvania, 24-26 June, 1994).

6) J. E. Stulga and B. J. McTiernan, "The Metallurgy and Applications of Rapidly Soliditied Alloy 625" (Paper presented at the International Conference on Rapidly Solidified Materials, San Diego, California, 3-5 February 1985), 397.

7) F. J. Rizzo and J. F. Radavich, "Microstructural Characterization of PM 625-Type Matcrials" (Paper presented at Superalloys 718, 625 and Various Derivatives, Pittsburgh, Pennsylvania, 23-26 June 1991). 